\title{
Understanding the Surface Characteristics of Biochar and Its Catalytic Activity for the Hydrodeoxygenation of Guaiacol
}

\author{
Indri Badria Adilina ${ }^{1, *}$, Robert Ronal Widjaya ${ }^{1}$, Luthfiana Nurul Hidayati ${ }^{1}$, Edi Supriadi ${ }^{1}$, Muhammad Safaat ${ }^{1}$, \\ Ferensa Oemry ${ }^{2}$, Elvi Restiawaty ${ }^{3,4}\left(\mathbb{D}\right.$, Yazid Bindar ${ }^{3,4}$ and Stewart F. Parker ${ }^{5}(\mathbb{D}$ \\ 1 Research Center for Chemistry, National Research and Innovation Agency, Kawasan PUSPIPTEK Serpong, \\ Tangerang Selatan 15314, Indonesia; robert.ronal.widjaya@lipi.go.id (R.R.W.); \\ luthfiana.nurul.hidayati@lipi.go.id (L.N.H.); edi.supriadi@lipi.go.id (E.S.); \\ muhammad.safaat@lipi.go.id (M.S.) \\ 2 Research Center for Physics, National Research and Innovation Agency, Kawasan PUSPIPTEK Serpong, \\ Tangerang Selatan 15314, Indonesia; ferensa.oemry@lipi.go.id \\ 3 Department of Chemical Engineering, Faculty of Industrial Technology, Institut Teknologi Bandung, \\ Ganesha 10, Bandung 40132, Indonesia; erestiawaty@che.itb.ac.id (E.R.); yazid@che.itb.ac.id (Y.B.) \\ 4 Department of Bioenergy Engineering and Chemurgy, Faculty of Industrial Technology, \\ Institut Teknologi Bandung, Jatinangor 45363, Indonesia \\ 5 ISIS Neutron and Muon Source, STFC Rutherford Appleton Laboratory, Chilton, Didcot, \\ Oxfordshire OX11 0QX, UK; stewart.parker@stfc.ac.uk \\ * Correspondence: indri.badria.adilina@lipi.go.id
}

\section{check for} updates

Citation: Adilina, I.B.; Widjaya, R.R.; Hidayati, L.N.; Supriadi, E.; Safaat, M.; Oemry, F.; Restiawaty, E.; Bindar, Y.; Parker, S.F. Understanding the Surface Characteristics of Biochar and Its Catalytic Activity for the Hydrodeoxygenation of Guaiacol. Catalysts 2021, 11, 1434. https:// doi.org/10.3390/catal11121434

Academic Editors: Christiaan Tempelman and Volkan Degirmenci

Received: 21 October 2021

Accepted: 22 November 2021

Published: 25 November 2021

Publisher's Note: MDPI stays neutral with regard to jurisdictional claims in published maps and institutional affiliations.

Copyright: (c) 2021 by the authors Licensee MDPI, Basel, Switzerland. This article is an open access article distributed under the terms and conditions of the Creative Commons Attribution (CC BY) license (https:/ / creativecommons.org/licenses/by/ $4.0 /)$.
Abstract: Biochar (BCR) was obtained from the pyrolysis of a palm-oil-empty fruit bunch at $773 \mathrm{~K}$ for $2 \mathrm{~h}$ and used as a catalyst for the hydrodeoxygenation (HDO) of guaiacol (GUA) as a bio-oil model compound. Brunauer-Emmet-Teller surface area analysis, $\mathrm{NH}_{3}$ and $\mathrm{CO}_{2}$-temperature-programmed desorption, scanning electron microscope-dispersive X-ray spectroscopy, CHN analysis and X-ray fluorescence spectroscopy suggested that macroporous and mesoporous structures were formed in BCR with a co-presence of hydrophilic and hydrophobic sites and acid-base behavior. A combination of infrared, Raman and inelastic neutron scattering (INS) was carried out to achieve a complete vibrational assignment of $\mathrm{BCR}$. The $\mathrm{CH}-\mathrm{OH}$ ratio in $\mathrm{BCR}$ is $\sim 5$, showing that the hydroxyl functional groups are a minority species. There was no evidence for any aromatic $\mathrm{C}-\mathrm{H}$ stretch modes in the infrared, but they are clearly seen in the INS and are the majority species, with a ratio of $\mathrm{sp}^{3}-\mathrm{CH}: \mathrm{sp}^{2}-\mathrm{CH}$ of $1: 1.3$. The hydrogen bound to $\mathrm{sp}^{2}-\mathrm{C}$ is largely present as isolated $\mathrm{C}-\mathrm{H}$ bonds, rather than adjacent $\mathrm{C}-\mathrm{H}$ bonds. The Raman spectrum shows the characteristic $\mathrm{G}$ band (ideal graphitic lattice) and three $\mathrm{D}$ bands (disordered graphitic lattice, amorphous carbon, and defective graphitic lattice) of $\mathrm{sp}^{2}$ carbons. Adsorbed water in BCR is present as disordered layers on the surface rather than trapped in voids in the material and could be removed easily by drying prior to catalysis. Catalytic testing demonstrated that BCR was able to catalyze the HDO of GUA, yielding phenol and cresols as the major products. Phenol was produced both from the direct demethoxylation of GUA, as well as through the demethylation pathway via the formation of catechol as the intermediate followed by deoxygenation.

Keywords: biochar; palm oil empty fruit bunch; hydrodeoxygenation; guaiacol

\section{Introduction}

The world has gradually shifted to renewable energy sources in an effort to reduce dependency on fossil fuels, as well as to address climate change and the global warming caused by excessive greenhouse gas emissions [1]. Indonesia, for example, has rolled out B30, a fuel blend of 30\% biofuel from fatty acid methyl esters (FAMEs) and 70\% conventional diesel, for nationwide commercial transportation in order to meet these targets by 2030 [2]. However, FAMEs are categorized as first-generation biofuels which rely heavily on food commodities and are, therefore, considered to be unsustainable, prompting 
massive deforestation as a result of industrial plantation expansion [3,4]. Second-generation biofuel, on the other hand, uses abundant and non-competitive biomass waste sources as their precursor. Among them, palm oil empty fruit bunches (POEFBs) are a potential source, since they are rich in lignocellulose feedstock [5].

The production of second-generation biofuels involves the pyrolysis of lignocellulose into bio-oil followed by upgrading via a hydrodeoxygenation (HDO) process to remove oxygen [3,6]. Bimetallic metal sulfides (e.g., NiMoS, CoMoS) have been one of the most widely studied catalysts for HDO [7-9], but the search for a suitable support material to increase the stability of the active metal centers, or act as the catalyst itself, remains a challenge. Activated carbons have been reported to offer higher stability in HDO systems compared to alumina and silica due to the weak acidity $[10,11]$, but the extensive microporosity is a drawback which inhibits reactions involving large molecules [12]. Macroporous and mesoporous materials have proven favorable as the relatively larger pores can improve molecular diffusion for the large molecules $[11,13,14]$.

Pyrolysis is considered to be a sustainable way to generate energy from bio-oil and syngas. However, biochar (BCR)—a solid carbon byproduct-is inevitably created in the production line $[6,15,16]$. BCR is a carbon-rich solid with easily tuned surface functionality and porosity [17-20]. The oxygen-containing functionalities of BCR, together with other functionalities upon modification, make the surface of this material both hydrophilic and hydrophobic, affecting the adsorption of the reactants for further activation $[11,21,22]$. It is known that the $-\mathrm{OH}, \mathrm{C}-\mathrm{O}$, and $\mathrm{C}=\mathrm{O}$ functional groups in $\mathrm{BCR}$ interact with phenol groups through $\mathrm{H}$ bonding $[23,24]$. This is beneficial for HDO, since the interaction of phenols via $\mathrm{H}$ bonding, such as that observed on silica and clay, is preferable compared to the chemisorption observed in alumina. This is because the formation of a strongly held carbonaceous species in the form of phenates was observed, leading to catalyst deactivation $[9,25]$. While BCR can be returned to farm fields as a fertilizer for carbon sequestration or other functional materials [26], it would be ideal to utilize the BCR as a catalyst for the HDO of bio-oil, creating a net-zero pyrolysis process.

Several authors have demonstrated the use of BCR as a catalyst for the esterification and transesterification of vegetable oils to produce FAME in high yields [27-29]. However, its utilization as a catalyst for bio-oil upgrading in second-generation biofuel production has not been fully explored [30-32], despite the fact that BCR is also produced during the biofuel production. The physicochemical properties of BCR have been demonstrated to vary significantly based on the type of raw biomass materials, the temperature and retention time used in pyrolysis and activation, or functionalization techniques employed [33-35]; hence, it is imperative to understand the surface characteristics of $B C R$, as tailoring the catalytic activity of BCR would be challenging without such knowledge.

Herein, we investigate the surface characteristics of BCR obtained from the pyrolysis of POEFB and apply it as a catalyst for the HDO of guaiacol (GUA) as a bio-oil model compound. The physicochemical properties of $\mathrm{BCR}$ were studied using Brunauer-EmmetTeller (BET) surface area analysis, $\mathrm{NH}_{3}$ - and $\mathrm{CO}_{2}$-temperature programmed desorption (TPD- $\mathrm{NH}_{3}, \mathrm{TPD}-\mathrm{CO}_{2}$ ), scanning electron microscope-dispersive $\mathrm{X}$-ray spectroscopy (SEMEDS), CHN analysis, $X$-ray fluorescence spectroscopy (XRF) and powder X-ray diffraction (XRD). A complete vibrational assignment of BCR was carried out by a combination of infrared, Raman and inelastic neutron scattering (INS) techniques to understand in detail the functional groups on the BCR surface, which greatly influence the surface characteristics and its catalytic activity towards HDO.

\section{Results and Discussion}

2.1. Characterization of $B C R$

2.1.1. Morphology and Elemental Analyses

The morphology of BCR examined by SEM (Figure 1) was observed to have irregular texturing with convoluted smooth and porous surfaces. Parts of the structure had a highly complex network of pores, channels and fibrous ridged surfaces. The release of volatiles 
during pyrolysis leads to the formation of bubbles, open and closed pores in BCR, similar to that observed for biochar obtained from palm kernel shells at pyrolysis temperatures higher than $773 \mathrm{~K}$ [36].
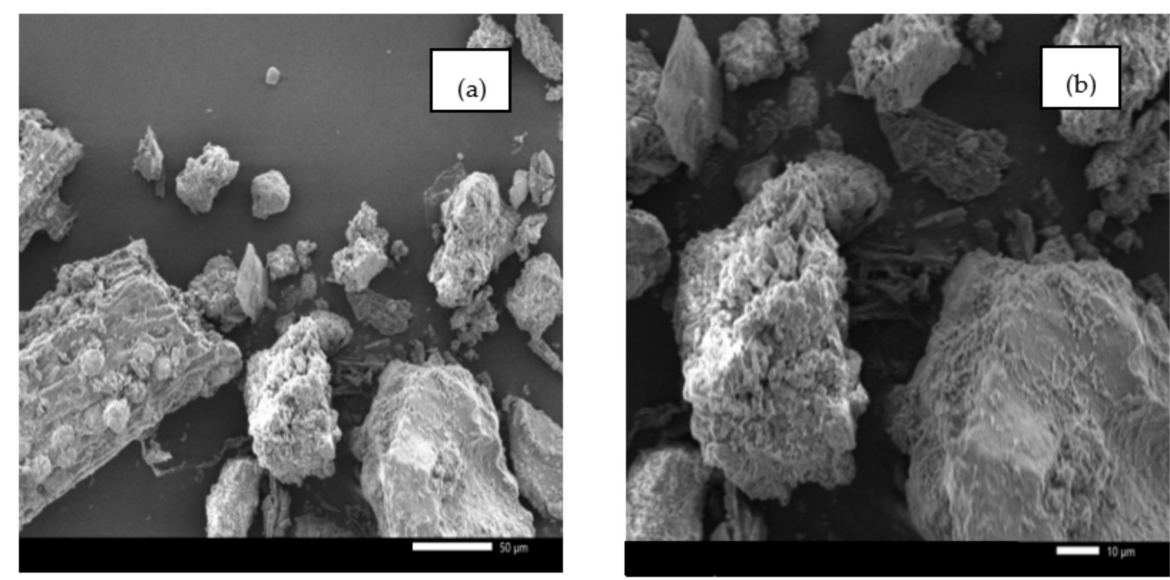

Figure 1. SEM analysis results of BCR: $(\mathbf{a}) \times 500$ and $(\mathbf{b}) \times 1000$ magnification.

The elemental analyses of BCR measured by CHN analysis, SEM-EDS and XRF are summarized in Table 1. The $\mathrm{H} / \mathrm{C}$ and $\mathrm{O} / \mathrm{C}$ molar ratios are informative to evaluate the hydrophilicity and hydrophobicity of BCR and as an indication of the development of aromatic structures [34,36,37]. Chen [34] evaluated the pyrolysis of various types of biomasses and found that the $\mathrm{H} / \mathrm{C}$ of the biomass precursor ranged from 1.4 to 1.8 and the $\mathrm{O} / \mathrm{C}$ ratio was found to be approximately $0.55-0.75$, indicating that the starting biomass has low aromaticity and a high aliphatic content. After pyrolysis, a significant decrease in the $\mathrm{H} / \mathrm{C}$ and $\mathrm{O} / \mathrm{C}$ atomic ratios was observed that decreased linearly as the pyrolysis temperature increased. In the case of $\mathrm{BCR}$, the $\mathrm{H} / \mathrm{C}$ and $\mathrm{O} / \mathrm{C}$ ratio was recorded as 0.80 and 0.34 , respectively, confirming that the surface of BCR was more hydrophobic than the reported biomass precursors. The loss of $\mathrm{H}$ and $\mathrm{O}$ during the pyrolysis process is a consequence of the dehydration and decarboxylation reactions of the weak linkages within the BCR structure, making the surface less hydrophilic with doped hydrophobic sites. The co-presence of both hydrophobic and hydrophilic sites has proven to be beneficial in heterogeneous catalysis involving substrates with varied polar functionalities [22,38]. The mineral content in BCR was dominated by $\mathrm{Si}, \mathrm{Ca}, \mathrm{K}$ and $\mathrm{Fe}$, with minor amounts of other minerals detected.

Table 1. Elemental analyses of BCR measured by CHN analyzer, SEM-EDS and XRF.

\begin{tabular}{cccc}
\hline Element & CHN/wt \% & SEM-EDS/wt \% & XRF/wt \% \\
\hline $\mathrm{C}$ & 40.59 & 66.71 & - \\
$\mathrm{H}$ & 2.72 & - & - \\
$\mathrm{N}$ & 3.53 & - & - \\
$\mathrm{O}$ & $53.16^{\mathrm{a}}$ & 30.45 & 4.98 \\
$\mathrm{Mg}$ & - & - & 3.76 \\
$\mathrm{Al}$ & - & - & 37.63 \\
$\mathrm{Si}$ & - & 1.18 & 4.62 \\
$\mathrm{P}$ & - & - & 3.88 \\
$\mathrm{~S}$ & - & - & 1.27 \\
$\mathrm{Cl}$ & - & - & 14.16 \\
$\mathrm{~K}$ & - & 0.52 & 18.45 \\
$\mathrm{Ca}$ & - & 0.56 & 0.48 \\
$\mathrm{Ti}$ & - & - & 0.56 \\
$\mathrm{Mn}$ & - & - & 9.51 \\
$\mathrm{Fe}$ & - & - & \\
\hline
\end{tabular}


Table 1. Cont.

\begin{tabular}{cccc}
\hline Element & CHN/wt \% & SEM-EDS/wt \% & XRF/wt \% \\
\hline H/C molar ratio & 0.80 & - & - \\
O/C molar ratio & - & 0.34 & - \\
\hline${ }^{a}$ Calculated by difference $(100 \%$ CHN content).
\end{tabular}

\subsubsection{BET Surface Area, Pore Size, and Total Acidity-Basicity}

The $\mathrm{N}_{2}$ isotherm of BCR is shown in Figure 2. This shows that the $\mathrm{N}_{2}$ adsorptiondesorption isotherms for BCR are classified as type II, which is a typical isotherm of macroporous materials (containing pores $>50 \mathrm{~nm}$ width) [14].

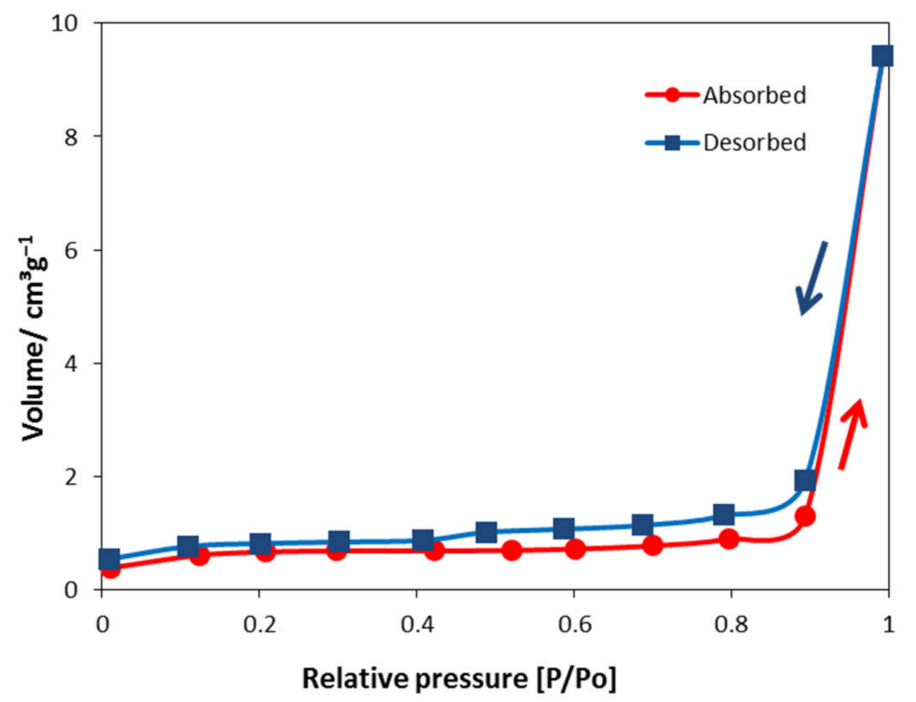

Figure 2. Adsorption-desorption isotherm curve of BCR.

The hysteresis loop of BCR is seen as an $\mathrm{H} 3$ type, as found in layered aggregates with gaps in mesoporous or macroporous materials [39]. It is a typical feature of non-rigid aggregates of plate-like particles, analogous to a Ni-biochar catalyst from rice husks [22,40]. The specific surface area, pore volume and pore size of the catalyst are listed in Table 2. The surface area was recorded as $2.14 \mathrm{~m}^{2} \mathrm{~g}^{-1}$. This low surface area of BCR is affected by the incomplete removal of volatile matter from biomass and has been reported for several untreated biochars from different feedstocks [23]. The mean pore size of BCR is $27.31 \mathrm{~nm}$, indicating the formation of a mesoporous structure in the material.

Table 2. BET surface area, total acidity, and total basicity of BCR measured by TPD-NH 3 and TPD- $\mathrm{CO}_{2}$.

\begin{tabular}{cc}
\hline Properties & Value \\
\hline BET surface area $/ \mathrm{m}^{2} \mathrm{~g}^{-1}$ & 2.14 \\
Pore size $/ \mathrm{nm}^{3}$ & 27.31 \\
Pore volume $/ \mathrm{cm}^{3} \mathrm{~g}^{-1}$ & 0.01 \\
\hline Total acidity $/ \mathrm{mmol} \mathrm{g}^{-1}$ & 0.15 \\
Total basicity $/ \mathrm{mmol} \mathrm{g}^{-1}$ & 0.50 \\
\hline
\end{tabular}

The total acidity and basicity of the catalysts were analyzed via TPD- $\mathrm{NH}_{3}$ and TPD$\mathrm{CO}_{2}$. The TPD profiles are presented in Figure 3 and the calculated acidity/basicity values are listed in Table 2. It has been reported that the TPD- $\mathrm{NH}_{3}$ for rice husk char are generally divided into three peaks: the peaks in the $100-230{ }^{\circ} \mathrm{C}$ range represent weak acidity; the peaks in the range of $230-380^{\circ} \mathrm{C}$ represent medium-strong acidity; and strong acidity is 
observed for peaks in the $380-500{ }^{\circ} \mathrm{C}$ range [41]. Our TPD- $\mathrm{NH}_{3}$ results show that the acidity peak of $\mathrm{BCR}$ was found in the range of $150-300^{\circ} \mathrm{C}$, demonstrating that $\mathrm{BCR}$ mostly contains weak acid sites with a total acidity value of $0.15 \mathrm{mmol} \mathrm{g}^{-1}$. Meanwhile, the TPD- $\mathrm{CO}_{2}$ shows a basicity peak in the range of $100-250{ }^{\circ} \mathrm{C}$, with a total basicity value of $0.50 \mathrm{mmol} \mathrm{g}^{-1}$. An increase in basic functional groups may be the result of charring and liming induced by the decreasing amount of acidic functional groups, as well as alkali salts separating from the organic compounds [42]. Hence, TPD measurements show that that BCR has both weak acid and base sites present on its surface. Yakovlev [43] suggested that the acidic-basic properties play an important role during GUA HDO because of the possible additional activation of oxy-compounds on the support surface, as found for $\mathrm{TiO}_{2}$ and $\mathrm{ZrO}_{2}$ [12].

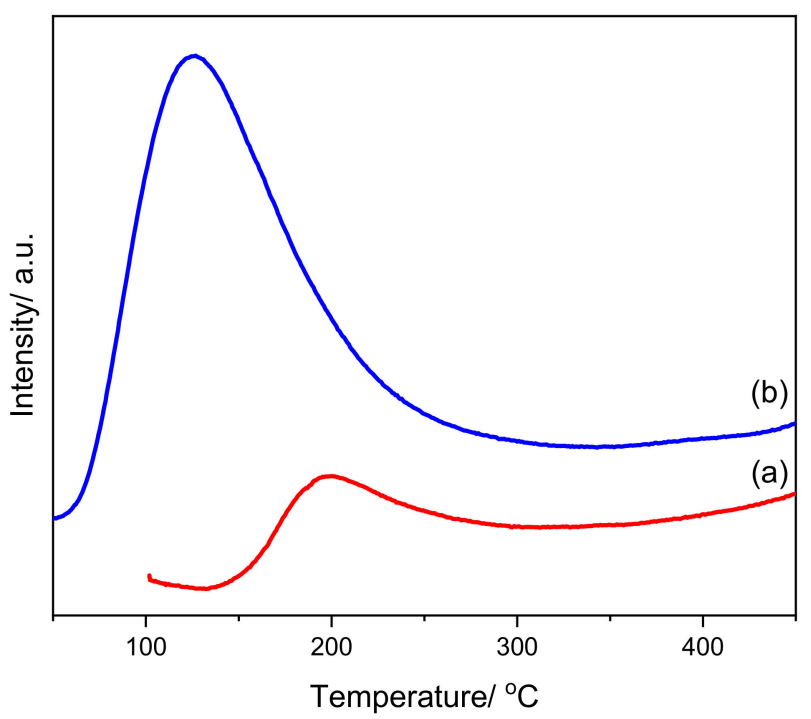

Figure 3. TPD profiles of BCR: (a) TPD-NH 3 and (b) TPD- $\mathrm{CO}_{2}$.

\subsubsection{Powder X-ray Diffraction Analysis}

The diffraction pattern of BCR is shown in Figure 4. The most prominent peak is seen at $2 \theta=26.7^{\circ}$ which is attributed to the stacking of the graphitic basal planes of the char crystallites [36]. The relatively high intensity and symmetry are a result of graphitization. The small features at $2 \theta=20.9$ and $29.5^{\circ}$ possibly show the presence of amorphous silica and fluorite [44], which was confirmed by XRF to be one of the major minerals contained in BCR. The broad band at $2 \theta=20-30^{\circ}$ indicates that the majority of the BCR remains amorphous [45].

\subsection{Vibrational Studies}

The infrared, Raman and INS spectra of BCR are shown in Figure 5 and selected regions are also presented in Figure 6. The infrared spectrum is very similar to that found for rice straw-derived biochar after pyrolysis at $773 \mathrm{~K}$ [46].

It is striking that the infrared, Raman and INS spectra are so different. This is a consequence of the different strengths of the techniques, emphasizing the need to have all three types of spectra available for a complete analysis. Thus, the infrared spectra are dominated by modes relating to the oxygen functionalities present, the Raman by the aromatic structure and the INS by modes involving displacement of hydrogen.

In the $\mathrm{C}-\mathrm{H}$ and $\mathrm{O}-\mathrm{H}$ stretch region $\left(2800-3700 \mathrm{~cm}^{-1}\right)$, the infrared spectrum (Figure $5 \mathrm{a}$ ) is dominated by the extremely intense and very broad $\left(\sim 800 \mathrm{~cm}^{-1}\right.$ FWHM) O-H stretch mode of hydroxyls. The intensity would suggest that there is a large number of these present; however, the MAPS INS spectrum (Figure 5d) shows that this is not the case. The intensity of an INS mode depends on the amplitude of motion, which in the harmonic approximation is inversely proportional to the transition energy, as described in the litera- 
ture [47]. Crucially, this does not depend on the electronic structure, unlike the infrared and Raman spectra, where the intensity derives from the dipole moment derivative and the polarizability tensor, respectively. This means that, to a reasonable degree of accuracy, in the INS, the ratio of the integrated intensity of the $\mathrm{C}-\mathrm{H}$ and $\mathrm{O}-\mathrm{H}$ stretch modes is a direct measure of their relative population. Figure 6 (top) shows a curve fit to the spectrum in this region. From this we find that the $\mathrm{CH}: \mathrm{OH}$ ratio is $\sim 5$, showing that the hydroxyls are a minority species. Their intensity in the infrared spectrum is misleading and occurs due to the large increase in the dipole moment derivative that is characteristic of hydrogen-bonded systems [48].

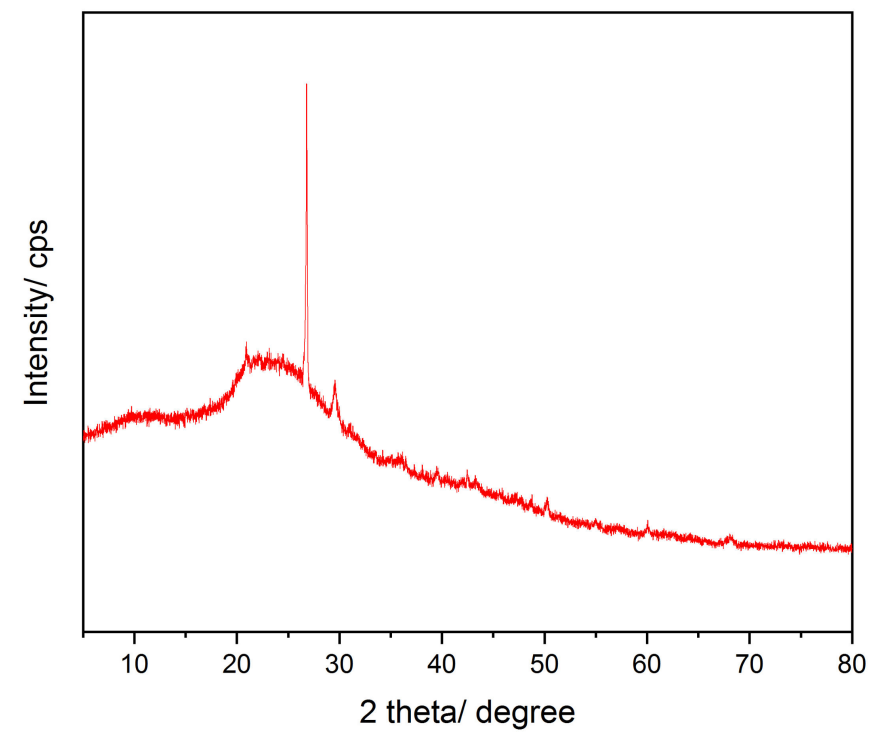

Figure 4. Powder XRD pattern of BCR.

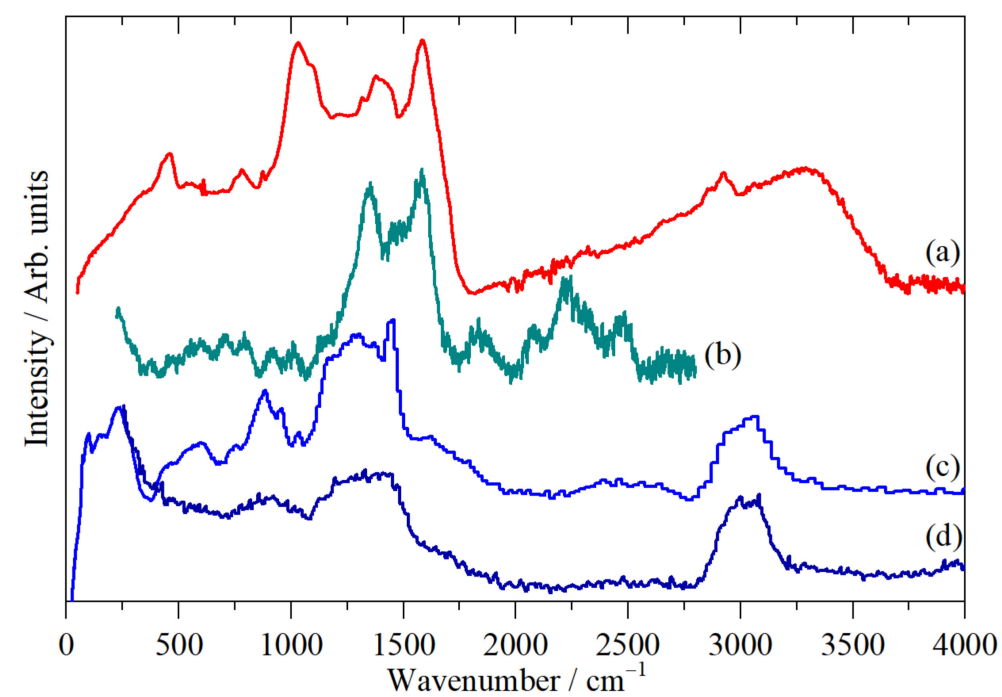

Figure 5. Vibrational spectra of BCR: (a) infrared at 298 K, (b) Raman at 298 K, (c) and (d) INS at 20 K recorded with TOSCA and MAPS, respectively.

The C-H stretch modes are seen at 2924 and $2855 \mathrm{~cm}^{-1}$ in the infrared spectrum, which is characteristic of aliphatic methylene groups [49]. The associated scissors mode is clearly seen in both the infrared and INS spectra at $1450 \mathrm{~cm}^{-1}$. There is no evidence for any aromatic $\mathrm{C}-\mathrm{H}$ stretch modes in the infrared spectrum, but they are clearly seen in the INS spectra and are the majority species. Figure 6 (top) shows that the ratio of $\mathrm{sp}^{3}-\mathrm{CH}: \mathrm{sp}^{2}-\mathrm{CH}$ is $1: 1.3$. 

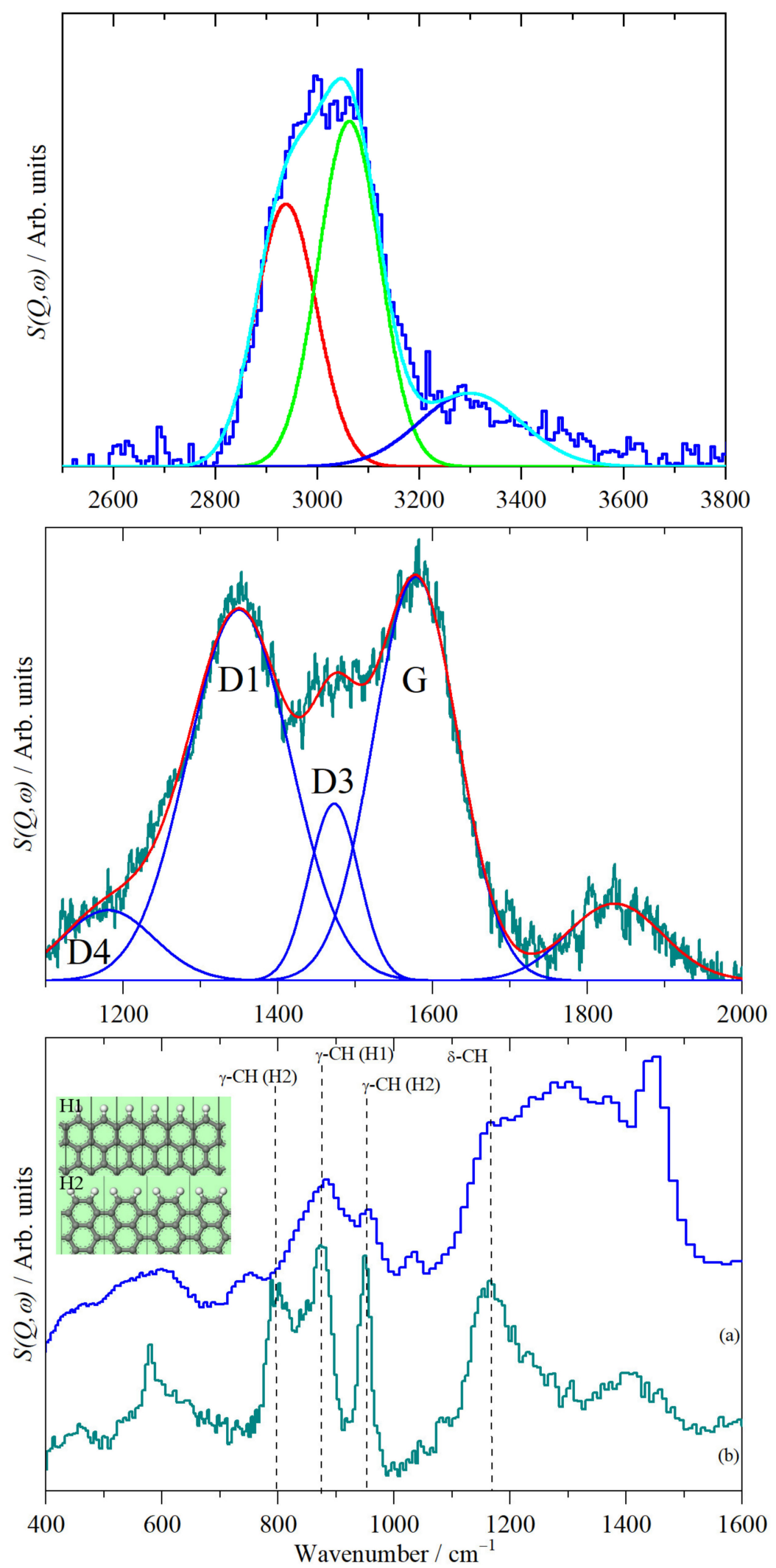

Figure 6. Top: Curve fit to the MAPS INS spectrum in the $\mathrm{C}-\mathrm{H}$ and $\mathrm{O}-\mathrm{H}$ stretch region. Middle: Curve fit to the Raman spectrum in the range of the $G$ and $D$ bands. Bottom: comparison of the TOSCA INS spectrum of biochar (a) and that of glassy carbon (b) [50] in the region of the aromatic C$\mathrm{H}$-bending modes. The inset shows the definition of $\mathrm{H} 1$ (an isolated $\mathrm{C}-\mathrm{H}$ bond) and $\mathrm{H} 2$ (two adjacent $\mathrm{C}-\mathrm{H}$ bonds) termination. 
In the $1000-1700 \mathrm{~cm}^{-1}$ range, the Raman spectrum shows the characteristic $\mathrm{D}$ and $\mathrm{G}$ bands of $\mathrm{sp}^{2}$ carbons. These are seen in a wide range of materials including soot [51], coal [52], industrial carbons [53] and carbon nanotubes [54]. Curve fitting the $1100-1600 \mathrm{~cm}^{-1}$ shows the presence of four bands-see Figure 6 (middle). Following Sadezky et al. [51], these are labeled as G-band $\left(1578 \mathrm{~cm}^{-1}\right.$, ideal graphitic lattice), D1 $\left(1350 \mathrm{~cm}^{-1}\right.$, disordered graphitic lattice, e.g., edges, defects, surface layers), D3 $\left(1472 \mathrm{~cm}^{-1}\right.$, amorphous carbon) and D4 (1180 $\mathrm{cm}^{-1}$ defective graphitic lattice). The G-band is also seen in the infrared spectrum. Carbons typically show a 2D band at $2700 \mathrm{~cm}^{-1}$ [54]. However, there is no evidence for this in our materials. The INS spectrum has a strong broad peak at $1370 \mathrm{~cm}^{-1}$, close to the D1-band. However, its intensity shows that it must originate from a hydrogenous mode; we assign it to the methylene wag. The infrared band at $1378 \mathrm{~cm}^{-1}$ could be either (or both) of the D1-band or the methylene wag.

The INS bands in the region 750-1200 $\mathrm{cm}^{-1}$ are characteristic of the in-plane $\left(\sim 1200 \mathrm{~cm}^{-1}\right)$ and out-of-plane (700-900 $\mathrm{cm}^{-1}$ ) C-H-bending modes of hydrogen that decorate the edges of the graphene sheets $[50,55]$. Figure 6 (bottom) shows a comparison of this region with that of a non-graphitizing glassy carbon [50]. While the peak at $955 \mathrm{~cm}^{-1}$ is consistent with it being one of the $\mathrm{H} 2$ peaks (two adjacent $\mathrm{C}-\mathrm{H}$ bonds, see inset of Figure 6 (bottom) for an illustration of $\mathrm{H} 1$ and $\mathrm{H} 2$ hydrogen), the corresponding peak at $795 \mathrm{~cm}^{-1}$ is absent. This suggests that the hydrogen is largely present as $\mathrm{H} 1$ (isolated $\mathrm{C}-\mathrm{H}$ bonds). The presence of the $\mathrm{D}$ bands in the Raman spectrum shows that the material is highly disordered. Hence, we assign the other modes in this region at 955,781 and $752 \mathrm{~cm}^{-1}$ to out-of-plane C-H-bending modes of isolated hydrogen perturbed by the presence of defects or oxygen functionalities. The very strong infrared band at $1099 \mathrm{~cm}^{-1}$ is assigned to the $\mathrm{C}-\mathrm{O}-\mathrm{C}$-stretching modes of the $\beta-\mathrm{O}-4$ linkages of lignin. There are a number of weak bands in the $200-700 \mathrm{~cm}^{-1}$ region in all three spectra. These are assigned to torsional modes of the graphene planes of the biochar.

The features at $1700-2500 \mathrm{~cm}^{-1}$ in the Raman spectrum are very difficult to assign, as we can find no precedent for them. The elemental analysis shows the presence of nitrogen. Therefore, the possibility of the presence of nitriles $-\mathrm{C} \equiv \mathrm{N}$ must be considered. These show strong bands in both the infrared and Raman spectra in the range $2200-2500 \mathrm{~cm}^{-1}$, depending on whether the nitrile is attached to $\mathrm{sp}^{2}-\mathrm{C}, \mathrm{sp}^{3}-\mathrm{C}$ or is conjugated [49]. While a nitrile would account for the $2230 \mathrm{~cm}^{-1}$ band, it would not explain the other bands in this region. Additionally, the absence of a corresponding band in the infrared spectrum militates against this assignment. We believe that the only plausible assignments are to resonance-enhanced overtones and combinations, because there are no functionalities present that could produce fundamental modes in this region. The observed modes and their vibrational assignments are summarized in Table 3.

Table 3. Transition energies $\left(\mathrm{cm}^{-1}\right)$ of $\mathrm{BCR}$ and vibrational assignments.

\begin{tabular}{cccc}
\hline FTIR & Raman & INS & Assignment $^{\mathbf{1}^{2}}$ \\
\hline 3300 & - & 3300 & $v \mathrm{OH}$ \\
\hline- & - & 3060 & $v \mathrm{sp}^{2}-\mathrm{CH}$ \\
\hline 2924 & - & 2940 & $v \mathrm{sp}^{3}-\mathrm{CH}_{2}$ \\
\hline 2855 & - & - & $\mathrm{G}+915$ \\
\hline- & 2475 & - & $\mathrm{D} 1+915$ \\
\hline- & 2230 & - & $\mathrm{D} 1+790$ \\
\hline- & 2070 & - & $2 \times 915$ \\
\hline 1585 & 1835 & - & aromatic ring stretch \\
& 1578 & G-band $)$ \\
\hline
\end{tabular}


Table 3. Cont.

\begin{tabular}{|c|c|c|c|}
\hline FTIR & Raman & INS & Assignment $^{1}$ \\
\hline 1450 & - & 1450 & $\mathrm{CH}_{2}$ scissors \\
\hline- & 1472 & - & $\begin{array}{c}\text { aromatic ring stretch } \\
\text { (D3-band) }\end{array}$ \\
\hline 1378 & - & 1370 & $\mathrm{CH}_{2}$ wag \\
\hline- & 1350 & 1300 & $\begin{array}{c}\text { aromatic ring stretch } \\
\text { (D1-band) }\end{array}$ \\
\hline- & 1180 & - & $\begin{array}{c}\text { aromatic ring stretch } \\
\text { (D4-band) }\end{array}$ \\
\hline- & - & 1160 & $\delta \mathrm{sp}^{2}-\mathrm{CH}$ \\
\hline 1099 & - & - & \multirow{2}{*}{$v \mathrm{C}-\mathrm{O}-\mathrm{C}$} \\
\hline 1028 & - & 1032 & \\
\hline- & - & 955 & $\gamma \mathrm{CH}$ \\
\hline- & 920 & - & - \\
\hline 874 & - & 882 & $\gamma \mathrm{CH}(\mathrm{H} 1)$ \\
\hline- & 790 & - & - \\
\hline 781 & - & - & $\gamma \mathrm{CH}$ \\
\hline- & - & 752 & $\gamma \mathrm{CH}$ \\
\hline- & 712 & - & - \\
\hline- & 604 & 605 & - \\
\hline- & - & 525 & \multirow{6}{*}{$\tau \mathrm{CC}$} \\
\hline 465 & 470 & 457 & \\
\hline 423 & - & 431 & \\
\hline- & - & 232 & \\
\hline- & - & 148 & \\
\hline- & - & 99 & \\
\hline
\end{tabular}

${ }_{1}^{1} v=$ stretch, $\delta=$ in-plane bend, $\gamma=$ out-of-plane bend, $\tau=$ torsion.

$\mathrm{BCR}$ readily absorbs water, which is removable by heating in a vacuum at $\sim 393 \mathrm{~K}$. The amount of water is significant. Drying resulted in an $11 \%$ weight loss. Figure 7 shows the infrared and INS spectra of the adsorbed water, generated from the difference spectra: as received-dried. In the INS spectrum shown in Figure 7a, it can be seen that the adsorbed water does not resemble that of ice, as shown in Figure $7 \mathrm{~b}$. The slope to the leading edge of the liberational modes at $4000-1000 \mathrm{~cm}^{-1}$ is typical of disordered forms of water, as seen on other types of carbon [50] and on metal oxides, e.g., those shown in [56]. Similarly, the infrared spectrum resembles that of liquid water much more closely than that of ice. This suggests that the water is present as disordered layers on the surface of the BCR rather than trapped in voids in the material.

\subsection{Catalytic HDO of GUA}

The catalytic HDO reaction of GUA was tested using BCR as the catalyst under 20 bar $\mathrm{H}_{2}$ pressure for $6 \mathrm{~h}$ without the use of a solvent. A control reaction without the presence of the catalyst was carried out and the results were compared to our previous study using pillared clay as the catalyst (PILC) [9]. Five products were identified in the liquid product mixture: phenol (1), o-cresol (2), p-cresol (3), catechol (4) and veratrole (5). The unidentified product mixtures were labeled as others; the results are summarized in Table 4 . The products (1)-(3) are HDO products with partial oxygen removal, whereas (4) and (5) are 
the result of a bimolecular transalkylation reaction and generally occur in the presence of Brønsted acid sites [57].

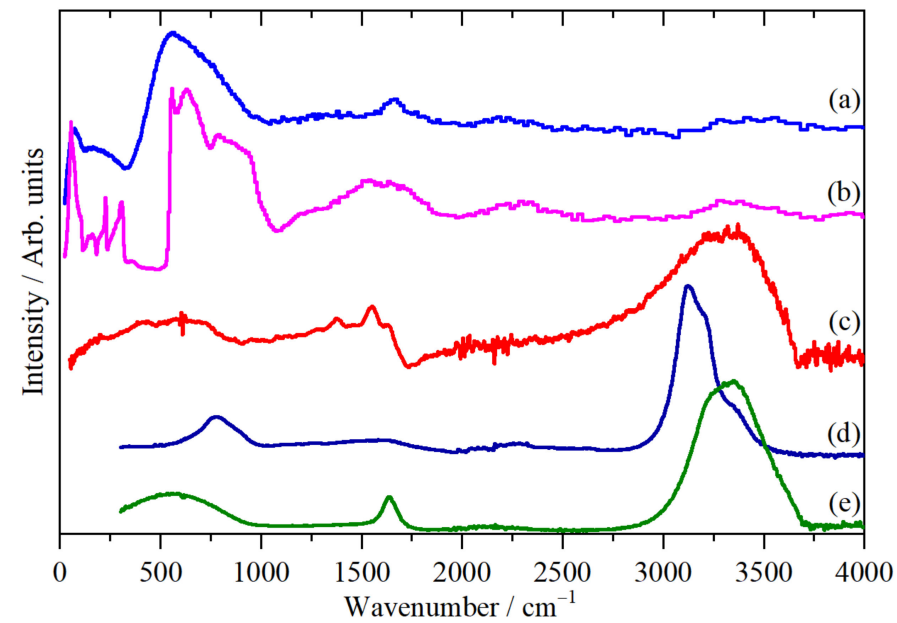

Figure 7. INS difference spectrum of (a) adsorbed water, (b) INS spectrum of ice $\mathrm{I}_{\mathrm{h}}$, (c) infrared difference spectrum of adsorbed water, (d) infrared spectrum of ice $I_{h}$ and (e) infrared spectrum of liquid water.

Table 4. HDO of GUA using BCR as the catalyst.<smiles>COc1ccccc1OCc1cccc(O)c1</smiles>

GUA<smiles>Cc1ccccc1O</smiles>

(2)<smiles>Cc1ccc(O)cc1</smiles>

(3)<smiles>Oc1ccccc1O</smiles>

(4)<smiles>COc1ccccc1OC</smiles>

(5)

\begin{tabular}{|c|c|c|c|c|c|c|c|c|c|c|}
\hline \multirow{2}{*}{ Catalyst } & \multirow{2}{*}{$\begin{array}{c}\text { Temperature } \\
\text { /K }\end{array}$} & \multirow{2}{*}{$\begin{array}{l}\text { Pressure/ } \\
\text { bar }\end{array}$} & \multirow{2}{*}{$\underset{\mathrm{h}}{\operatorname{Time}}$} & \multirow{2}{*}{$\begin{array}{c}\text { Conversion } \\
/ \%\end{array}$} & \multicolumn{5}{|c|}{ Product Distribution/\% } & \multirow[b]{2}{*}{ Others } \\
\hline & & & & & (1) & (2) & (3) & (4) & (5) & \\
\hline BCR & 523 & 20 & 6 & 100 & 60 & 10 & 19 & 0 & 0 & 11 \\
\hline PILC [9] & 623 & 20 & 6 & 78 & 42 & 10 & 5 & 6 & 5 & 32 \\
\hline No catalyst & 523 & 20 & 6 & 22 & 0 & 0 & 0 & 0 & 60 & 40 \\
\hline
\end{tabular}

The reaction testing data show that the BCR was able to convert all the GUA $(100 \%)$ yielding $60 \%$ (1), $10 \%$ (2) and 19\% (3) as the major HDO products with no detection of (4) and (5). The selectivity towards the desired products (1)-(3), in particular for (1), was higher when BCR was used as the catalyst, as compared to PILC. Notably, no benzene ring hydrogenation products were formed in either case. The higher selectivity of $\mathrm{BCR}$ most likely arises from the presence of both weak acid and base sites, similar to $\mathrm{ZrO}_{2}$ [12]. In addition, the contribution of both hydrophobic and hydrophilic sites in BCR allows the adsorption stability of GUA on the surface to be increased. As reported by Wang [22], the multiple absorption modes in a Ni-biochar catalyst were able to facilitate the adsorption/activation of the $\mathrm{C}-\mathrm{O}$ functionality in vanillin and the aliphatic $\mathrm{C}-\mathrm{C}$ in eugenol, enhancing its hydrogenation activity.

It is noteworthy that, although no metals were immobilized on $B C R$, we suggest that the iron contained in BCR (9.51 $\mathrm{wt} \%$ ) played a role in the dissociation of $\mathrm{H}_{2}$ during $\mathrm{HDO}$, as our reaction conditions are not far from those generally used in an iron catalyzed FischerTropsch process [58]. The activation of guaiacol on Fe-based catalysts has been reported to favour $\mathrm{C}-\mathrm{O}$ bond breaking at the expense of $\mathrm{C}-\mathrm{C}$ bond breaking $[59,60]$. The Fe catalysts show a low level of activity in the hydrogenation of aromatic rings, resulting in benzene, 
toluene, xylenes (BTX) and phenol as the HDO products. The chemical mechanisms are catalyzed in the presence of the supported Fe particles, which supply the active $\mathrm{H}$ species coming from the dissociation of $\mathrm{H}_{2}$ on the metal phase. A different selectivity and mechanism are observed over supported Ni-based catalysts, which provides a higher level of selectivity for the hydrogenation of the benzene ring [61].

The presence of potassium in BCR $(14.16 \mathrm{wt} \%)$ correlates with the reduction in the total acidity and changes the acid-base balance of $\mathrm{BCR}$, which positively influenced the selectivity of the catalyst, as reported in the case of potassium-modified NiMo and CoMoalumina catalysts [7]. Without the presence of a catalyst, a GUA conversion rate of only $20 \%$ was obtained, yielding $60 \%$ of (5) with no formation of the HDO products (1)-(3). At the current stage, we speculate that (5) was formed via a free radical mechanism rather than transalkylation in the absence of a catalyst, similar to that reported in the pyrolysis of guaiacol [62].

In order to evaluate the reaction profile, we examined the catalytic activity of BCR under different reaction times. As shown in Figure 8, product (1) was rapidly, and largely, formed by $0.5 \mathrm{~h}$, resulting in a $50 \%$ yield. With increasing reaction time, (1) continuously increased to a $60 \%$ yield at $3 \mathrm{~h}$, but no further increase in the yield was seen with a prolonged time of $6 \mathrm{~h}$. Products (2) and (3) were also formed faster in the first $0.5 \mathrm{~h}$, with no significant changes in their yields at 3 and $6 \mathrm{~h}$. Interestingly, a $17 \%$ yield of (4) was observed at $0.5 \mathrm{~h}$, which decreased with time. Only $3 \%$ of (4) was seen at $3 \mathrm{~h}$ and none was detected at $6 \mathrm{~h}$. This indicates that (4) is an intermediate in the production of (1). It has been reported that the hydrogenolysis of the methyl-oxygen bond (demethylation) of the methoxy group of GUA to form catechol is the first stage of the reaction, followed by a second stage leading to the elimination of one of the hydroxyl groups (deoxygenation) to produce phenol $[12,63,64]$. Over the BCR catalyst, phenol was also produced via the direct demethoxylation of GUA. Fan [41] has reported that the impregnation of $\mathrm{Ni}$ on rice husk char was able to provide a $100 \%$ GUA conversion rate and had an $11.4 \%$ selectivity for hydrocarbons. Work from Santos [65] shows that complete HDO conversion of vanillin was achieved over Pd-biochar catalysts resulting in $92 \%$ selectivity of p-cresol. An MoWC bimetallic carbide catalyst has been reported to exhibit higher catalytic activity and oxygenfree aromatic hydrocarbon selectivity compared to the monometallic MoC in the HDO of GUA [66]. Our previous work has also shown that immobilization of bimetallic NiMoS on PILC further increases the yield and selectivity of HDO products [9]. In order to increase the catalytic activity and selectivity toward benzene ring hydrogenation products, we will investigate BCR as a catalyst support for bimetallic and metal sulfide catalysts in future HDO studies.

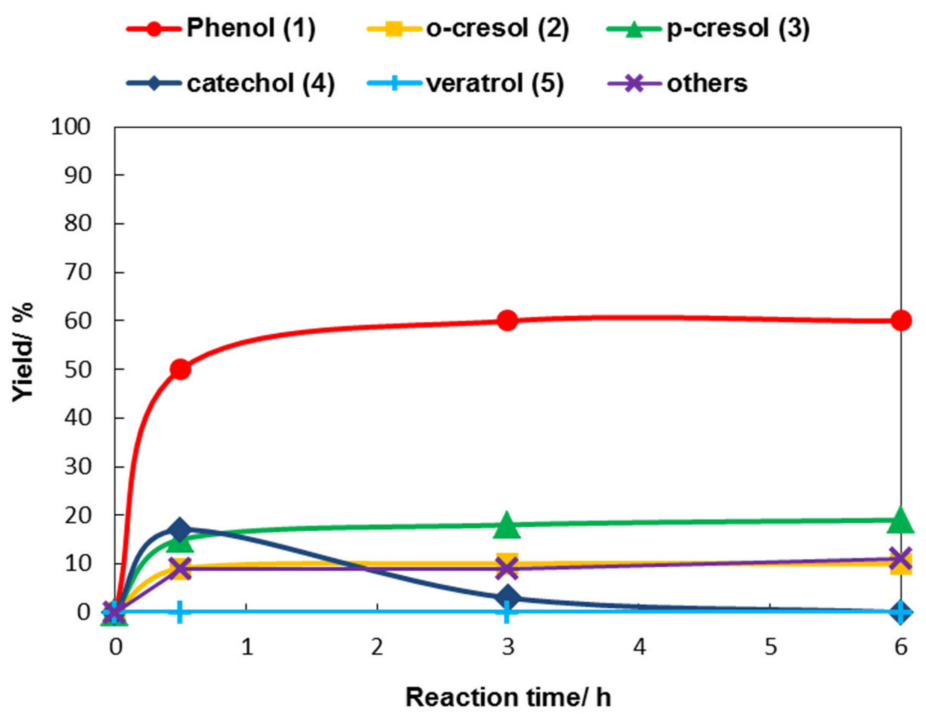

Figure 8. HDO of GUA over BCR catalyst at various reaction times. 


\section{Materials and Methods}

\subsection{Materials}

$\mathrm{BCR}$ was produced through the pyrolysis of POEFB at $T=773 \mathrm{~K}$ for $2 \mathrm{~h}$. The heating process started at room temperature and was raised to $773 \mathrm{~K}$ at a heating rate of $6{ }^{\circ} \mathrm{C} / \mathrm{min}$ (75 min) followed by a holding period for $45 \mathrm{~min}$ at $773 \mathrm{~K}$. GUA and reference products were purchased from Sigma-Aldrich (Gillingham, UK) and used without further purification.

\subsection{Characterization of $B C R$}

The morphology and elemental analyses were measured using SEM-EDS JSM-IT200 Jeol operated at $20 \mathrm{kV}$ and by a Bruker XRF. The CHN analysis was carried out on a LECO CHN628 Series Elemental Determinator (LECO, St. Joseph, MI, USA). Surface areas and pore size were analyzed based on the BET method using Micromeritics TriStar II 3020 Version 2.00 (Micromeritics, Norcross, GA, USA). The samples were degassed at $573 \mathrm{~K}$ prior to the measurement. TPD- $\mathrm{NH}_{3}$ and TPD- $\mathrm{CO}_{2}$ were measured on a Micromeritics Chemisorb 2750 (Micromeritics, Norcross, GA, USA) and XRD was carried out on a Panalytical AERIS (Malvern Panalytical, Almelo, Netherlands) using $\mathrm{CuK} \alpha(\lambda=0.15406)$ at $40 \mathrm{kV}$ and $15 \mathrm{~mA}$. The infrared spectra were measured on a Bruker Vertex 70 (Bruker UK Limited, Coventry, UK) using the Bruker Diamond ATR accessory (Bruker UK Limited, Coventry, UK). Raman spectroscopy was performed using a Horiba Scientific LabSpec 6 spectrometer (Horiba, Villeneuve-d'Ascq, France), with $532 \mathrm{~nm}$ excitation. The inelastic neutron scattering (INS) of BCR was carried out at the ISIS Neutron and Muon Source, Oxfordshire, United Kingdom [67] using the spectrometers TOSCA [68] and MAPS [69,70]. As explained in more detail in the literature [69], the two spectrometers are complementary. TOSCA provides good resolution in the $0-2000 \mathrm{~cm}^{-1}$ region, while MAPS enables access to the $\mathrm{C}-\mathrm{H}$ and $\mathrm{O}-\mathrm{H}$ stretch regions $\left(2800-4000 \mathrm{~cm}^{-1}\right)$. Prior to the analyses, the sample was dried at $383 \mathrm{~K}$ in vacuo overnight and the INS spectra were recorded at $20 \mathrm{~K}$ for $\sim 6 \mathrm{~h}$.

\subsection{Catalytic Testing}

The conversion of GUA was performed following the HDO procedure previously reported in our work [9]. In brief, the BCR catalyst $(0.5 \mathrm{~g}, 5 \mathrm{wt} \%)$ and GUA (10 g) were placed in a high-pressure autoclave and reacted at $523 \mathrm{~K}$ and $20 \mathrm{bar}_{2}$ for varying reaction times $(0.5-6 \mathrm{~h})$. The BCR was dried overnight at $383 \mathrm{~K}$ prior to catalyst testing. After the reaction, the liquid product was extracted using dichloromethane and analyzed on an Agilent GC/MS 7890B system (Agilent, Santa Clara, CA, USA) with an HP-5MS UI column. Products with lower boiling points, such as cyclohexane and cyclohexanone, were measured using an Agilent 7890A GC/FID system (Agilent, Santa Clara, CA, USA) equipped with a DB-WAX column. However, they were only found in trace amounts and are, therefore, not included in the mass balance calculation.

\section{Conclusions}

BCR from POEFB was developed as a new HDO catalyst. An evaluation of the physicochemical properties shows that pyrolysis at $773 \mathrm{~K}$ for $2 \mathrm{~h}$ generated amorphous BCR with macroporous and mesoporous structures that have irregular texturing and convoluted smooth and porous surfaces. The co-presence of hydrophilic and hydrophobic sites was observed based on the $\mathrm{H} / \mathrm{C}$ and $\mathrm{O} / \mathrm{C}$ molar ratios of $\mathrm{BCR}$ as compared to reported biomass precursors. BCR shows both acid and base behavior. $\mathrm{Si}, \mathrm{Ca}, \mathrm{K}$ and Fe were found to be the major minerals present. The co-existence of aliphatic and aromatic $\mathrm{C}-\mathrm{H}$ stretch modes suggests that the pyrolysis of POEFB produced incomplete carbonization, leading to a model of BCR having a slightly higher population of aromatic components than aliphatic compounds. The INS clearly shows that hydroxyls are only present as a minority species, despite the strength of the bands in the infrared spectrum. Raman spectroscopy shows that there are graphitic domains present but that there is also considerable disorder as shown by the presence of the D3 and D4 bands. Adsorbed water in BCR is present as disordered layers on the surface rather than trapped in voids in the material. The catalytic 
HDO of GUA over the BCR yielded phenol and cresols as the major products. Phenol was produced either from a two-step demethoxylation-deoxygenation pathway via the intermediate compound catechol, or by a one-step demethoxylation of GUA directly to phenol. No benzene ring hydrogenation products were formed in the reaction conditions of this experiment. Although no metals were immobilized on BCR, we speculate that the iron contained in $\mathrm{BCR}$ played a role in $\mathrm{H}_{2}$ dissociation during $\mathrm{HDO}$, whereas potassium potentially correlates with the reduction in the total acidity and changes the acid-base balance of BCR, which positively influenced the catalyst selectivity. These results provide reference information for the use of $\mathrm{BCR}$ as a catalyst for $\mathrm{HDO}$, demonstrating how further optimization of the catalytic activity may be achieved by using BCR as a catalyst support for the widely studied bimetallic and metal sulfide HDO catalysts.

Author Contributions: Conceptualization, I.B.A.; experimental work, I.B.A.; R.R.W.; L.N.H.; M.S.; E.S.; E.R.; Y.B.; S.F.P.; data analysis, I.B.A.; F.O.; S.F.P.; writing—original draft preparation, I.B.A.; F.O.; S.F.P.; writing-review and editing, I.B.A.; S.F.P.; funding acquisition, I.B.A.; S.F.P. All authors have read and agreed to the published version of the manuscript.

Funding: This research was supported by the Science and Technology Facilities Council (STFC), the Newton Fund (STFC_IND_142), and the National Research and Innovation Agency (BRIN).

Data Availability Statement: Data is available upon request to the corresponding authors.

Acknowledgments: The UK-Indonesia Science and Technology Partnership on STEM Skills for Large Facilities, supported by the Newton Fund and delivered by STFC, ISIS, Diamond, and LIPI is gratefully thanked for the financial support of this project. The STFC Rutherford Appleton Laboratory is thanked for access to neutron beam facilities via RB2010226. We also thank the facilities from Advanced Characterization Laboratories Serpong, National Research and Innovation Agency, through E- Layanan Sains, Badan Riset dan Inovasi Nasional.

Conflicts of Interest: The authors declare no conflict of interest.

\section{References}

1. Scarlat, N.; Dallemand, J.F.; Monforti-Ferrario, F.; Nita, V. The role of biomass and bioenergy in a future bioeconomy: Policies and facts. Environ. Dev. 2015, 15, 3-34. [CrossRef]

2. Prananta, W.; Kubiszewski, I. Assessment of Indonesia's future renewable energy plan: A meta-analysis of biofuel energy return on investment (eroi). Energies 2021, 14, 2803. [CrossRef]

3. Naik, S.N.; Goud, V.V.; Rout, P.K.; Dalai, A.K. Production of first and second generation biofuels: A comprehensive review. Renew. Sustain. Energy Rev. 2010, 14, 578-597. [CrossRef]

4. Rulli, M.C.; Bellomi, D.; Cazzoli, A.; De Carolis, G.; D'Odorico, P. The water-land-food nexus of first-generation biofuels. Sci. Rep. 2016, 6, 22521. [CrossRef]

5. Sudiyani, Y.; Styarini, D.; Triwahyuni, E.; Sudiyarmanto; Sembiring, K.C.; Aristiawan, Y.; Abimanyu, H.; Han, M.H. Utilization of biomass waste empty fruit bunch fiber of palm oil for bioethanol production using pilot-Scale unit. Energy Procedia 2013, 32, 31-38. [CrossRef]

6. Ruddy, D.A.; Schaidle, J.A.; Ferrell, J.R.; Wang, J.; Moens, L.; Hensley, J.E. Recent advances in heterogeneous catalysts for bio-oil upgrading via "ex situ catalytic fast pyrolysis": Catalyst development through the study of model compounds. Green Chem. 2014, 16, 454-490. [CrossRef]

7. Mora-Vergara, I.D.; Hernández Moscoso, L.; Gaigneaux, E.M.; Giraldo, S.A.; Baldovino-Medrano, V.G. Hydrodeoxygenation of guaiacol using NiMo and CoMo catalysts supported on alumina modified with potassium. Catal. Today 2018, 302, 125-135. [CrossRef]

8. Lin, Y.C.; Li, C.L.; Wan, H.P.; Lee, H.T.; Liu, C.F. Catalytic hydrodeoxygenation of guaiacol on Rh-based and sulfided CoMo and NiMo catalysts. Energy Fuels 2011, 25, 890-896. [CrossRef]

9. Adilina, I.B.; Rinaldi, N.; Simanungkalit, S.P.; Aulia, F.; Oemry, F.; Stenning, G.B.G.; Silverwood, I.P.; Parker, S.F. Hydrodeoxygenation of Guaiacol as a Bio-Oil Model Compound over Pillared Clay-Supported Nickel-Molybdenum Catalysts. J. Phys. Chem. C 2019, 123, 21429-21439. [CrossRef]

10. Duchet, J.C.; van Oers, E.M.; de Beer, V.H.J.; Prins, R. Carbon-supported sulfide catalysts. J. Catal. 1983, 80, 386-402. [CrossRef]

11. Figueiredo, J.L.; Pereira, M.F.R. The role of surface chemistry in catalysis with carbons. Catal. Today 2010, 150, 2-7. [CrossRef]

12. He, Z.; Wang, X. Hydrodeoxygenation of model compounds and catalytic systems for pyrolysis bio-oils upgrading. Catal. Sustain. Energy 2012, 1, 28-52. [CrossRef] 
13. Galarneau, A.; Abid, Z.; Said, B.; Didi, Y.; Szymanska, K.; Jarzebski, A.; Tancret, F.; Hamaizi, H.; Bengueddach, A.; Di Renzo, F.; et al. Synthesis and textural characterization of mesoporous and meso-/macroporous silica monoliths obtained by spinodal decomposition. Inorganics 2016, 4, 9. [CrossRef]

14. Sotomayor, F.J.; Cychosz, K.A.; Thommes, M. Characterization of Micro/Mesoporous Materials by Physisorption: Concepts and Case Studies. Acc. Mater. Surf. Res. 2018, 3, 34-50.

15. Shariff, A.; Aziz, N.S.M.; Abdullah, N. Slow Pyrolysis of Oil Palm Empty Fruit Bunches for Biochar Production and Characterisation. J. Phys. Sci. 2014, 25, 97-112. [CrossRef]

16. Cantrell, K.B.; Hunt, P.G.; Uchimiya, M.; Novak, J.M.; Ro, K.S. Impact of pyrolysis temperature and manure source on physicochemical characteristics of biochar. Bioresour. Technol. 2012, 107, 419-428. [CrossRef]

17. De Mendonça, F.G.; da Cunha, I.T.; Soares, R.R.; Tristão, J.C.; Lago, R.M. Tuning the surface properties of biochar by thermal treatment. Bioresour. Technol. 2017, 246, 28-33. [CrossRef] [PubMed]

18. Pourhosseini, S.E.M.; Norouzi, O.; Naderi, H.R. Study of micro/macro ordered porous carbon with olive-shaped structure derived from Cladophora glomerata macroalgae as efficient working electrodes of supercapacitors. Biomass Bioenergy 2017, 107, 287-298. [CrossRef]

19. Cui, L.; Fan, Q.; Sun, J.; Quan, G.; Yan, J.; Hina, K.; Wang, H.; Zhang, Z.; Hussain, Q. Changes in surface characteristics and adsorption properties of 2,4,6-trichlorophenol following Fenton-like aging of biochar. Sci. Rep. 2021, 11, 4293. [CrossRef] [PubMed]

20. Balajii, M.; Niju, S. Biochar-derived heterogeneous catalysts for biodiesel production. Environ. Chem. Lett. 2019, 17, 1447-1469. [CrossRef]

21. Fraga, M.A.; Jordão, E.; Mendes, M.J.; Freitas, M.M.A.; Faria, J.L.; Figueiredo, J.L. Properties of carbon-supported platinum catalysts: Role of carbon surface sites. J. Catal. 2002, 209, 355-364. [CrossRef]

22. Wang, Y.; Shao, Y.; Zhang, L.; Zhang, S.; Wang, Y.; Xiang, J.; Hu, S.; Hu, G.; Hu, X. Co-presence of hydrophilic and hydrophobic sites in $\mathrm{Ni}$ /biochar catalyst for enhancing the hydrogenation activity. Fuel 2021, 293, 120426. [CrossRef]

23. Lee, J.; Kim, K.H.; Kwon, E.E. Biochar as a Catalyst. Renew. Sustain. Energy Rev. 2017, 77, 70-79. [CrossRef]

24. Liu, W.J.; Zeng, F.X.; Jiang, H.; Zhang, X.S. Preparation of high adsorption capacity bio-chars from waste biomass. Bioresour. Technol. 2011, 102, 8247-8252. [CrossRef]

25. Popov, A.; Kondratieva, E.; Goupil, J.M.; Mariey, L.; Bazin, P.; Gilson, J.P.; Travert, A.; Maugé, F. Bio-oils hydrodeoxygenation: Adsorption of phenolic molecules on oxidic catalyst supports. J. Phys. Chem. C 2010, 114, 15661-15670. [CrossRef]

26. Liu, W.J.; Jiang, H.; Yu, H.Q. Development of Biochar-Based Functional Materials: Toward a Sustainable Platform Carbon Material. Chem. Rev. 2015, 115, 12251-12285. [CrossRef] [PubMed]

27. Lokman, I.M.; Rashid, U.; Taufiq-Yap, Y.H.; Yunus, R. Methyl ester production from palm fatty acid distillate using sulfonated glucose-derived acid catalyst. Renew. Energy 2015, 81, 347-354. [CrossRef]

28. Li, M.; Zheng, Y.; Chen, Y.; Zhu, X. Biodiesel production from waste cooking oil using a heterogeneous catalyst from pyrolyzed rice husk. Bioresour. Technol. 2014, 154, 345-348. [CrossRef] [PubMed]

29. Dehkhoda, A.M.; Ellis, N. Biochar-based catalyst for simultaneous reactions of esterification and transesterification. Catal. Today 2013, 207, 86-92. [CrossRef]

30. Van Nguyen, D.; Do, H.N.; Do, H.N.; Long, Q.N. One-step preparation of rice husk-based magnetic biochar and its catalytic activity for p-nitrophenol degradation. Chem. Eng. Trans. 2020, 78, 379-384. [CrossRef]

31. Wang, Y.Y.; Ling, L.L.; Jiang, H. Selective hydrogenation of lignin to produce chemical commodities by using a biochar supported Ni-Mo2C catalyst obtained from biomass. Green Chem. 2016, 18, 4032-4041. [CrossRef]

32. Cao, X.; Sun, S.; Sun, R. Application of biochar-based catalysts in biomass upgrading: A review. RSC Adv. 2017, 7, 48793-48805 [CrossRef]

33. Nabais, J.M.V.; Nunes, P.; Carrott, P.J.M.; Ribeiro Carrott, M.M.L.; García, A.M.; Díaz-Díez, M.A. Production of activated carbons from coffee endocarp by CO2 and steam activation. Fuel Process. Technol. 2008, 89, 262-268. [CrossRef]

34. Chen, Y.; Zhang, X.; Chen, W.; Yang, H.; Chen, H. The structure evolution of biochar from biomass pyrolysis and its correlation with gas pollutant adsorption performance. Bioresour. Technol. 2017, 246, 101-109. [CrossRef] [PubMed]

35. Kołtowski, M.; Charmas, B.; Skubiszewska-Zięba, J.; Oleszczuk, P. Effect of biochar activation by different methods on toxicity of soil contaminated by industrial activity. Ecotoxicol. Environ. Saf. 2017, 136, 119-125. [CrossRef]

36. Wang, P.; Zhang, J.; Shao, Q.; Wang, G. Physicochemical properties evolution of chars from palm kernel shell pyrolysis. J. Therm. Anal. Calorim. 2018, 133, 1271-1280. [CrossRef]

37. Bakhtiar, M.H.A.B.M.; Sari, N.B.A.; Yaacob, A.B.; Yunus, M.F.B.M.; Ismail, K.B. Characterization of oil palm Empty Fruit Bunch (EFB) biochar activated with potassium hydroxide under different pyrolysis temperature. J. Eng. Sci. Technol. 2019, 14, $2792-2807$.

38. Zhong, Y.; Deng, Q.; Yao, Q.; Lu, C.; Zhang, P.; Li, H.; Wang, J.; Zeng, Z.; Zou, J.J.; Zou, J.J.; et al. Functionalized Biochar with Superacidity and Hydrophobicity as a Highly Efficient Catalyst in the Synthesis of Renewable High-Density Fuels. ACS Sustain. Chem. Eng. 2020, 8, 7785-7794. [CrossRef]

39. Cui, X.; Shao, H.; Song, Y.; Yang, S.; Wang, F.; Liu, H. Preparation of highly interconnected porous polymer microbeads: Via suspension polymerization of high internal phase emulsions for fast removal of oil spillage from aqueous environments. RSC Adv. 2019, 9, 25730-25738. [CrossRef] 
40. Cychosz, K.A.; Guillet-Nicolas, R.; García-Martínez, J.; Thommes, M. Recent advances in the textural characterization of hierarchically structured nanoporous materials. Chem. Soc. Rev. 2017, 46, 389-414. [CrossRef]

41. Fan, X.D.; Wu, Y.J.; Tu, R.; Sun, Y.; Jiang, E.C.; Xu, X.W. Hydrodeoxygenation of guaiacol via rice husk char supported Ni based catalysts: The influence of char supports. Renew. Energy 2020, 157, 1035-1045. [CrossRef]

42. Usman, A.R.A.; Abduljabbar, A.; Vithanage, M.; Ok, Y.S.; Ahmad, M.; Ahmad, M.; Elfaki, J.; Abdulazeem, S.S.; Al-Wabel, M.I. Biochar production from date palm waste: Charring temperature induced changes in composition and surface chemistry. J. Anal. Appl. Pyrolysis 2015, 115, 392-400. [CrossRef]

43. Yakovlev, V.A.; Khromova, S.A.; Sherstyuk, O.V.; Dundich, V.O.; Ermakov, D.Y.; Novopashina, V.M.; Lebedev, M.Y.; Bulavchenko, O.; Parmon, V.N. Development of new catalytic systems for upgraded bio-fuels production from bio-crude-oil and biodiesel. Catal. Today 2009, 144, 362-366. [CrossRef]

44. Waqas, M.; Aburiazaiza, A.S.; Miandad, R.; Rehan, M.; Barakat, M.A.; Nizami, A.S. Development of biochar as fuel and catalyst in energy recovery technologies. J. Clean. Prod. 2018, 188, 477-488. [CrossRef]

45. He, S.; Zhong, L.; Duan, J.; Feng, Y.; Yang, B.; Yang, L. Bioremediation of wastewater by iron Oxide-Biochar nanocomposites loaded with photosynthetic bacteria. Front. Microbiol. 2017, 8, 823. [CrossRef] [PubMed]

46. Wu, W.; Yang, M.; Feng, Q.; McGrouther, K.; Wang, H.; Lu, H.; Chen, Y. Chemical characterization of rice straw-derived biochar for soil amendment. Biomass Bioenergy 2012, 47, 268-276. [CrossRef]

47. Silverwood, I.P.; Hamilton, N.G.; Laycock, C.J.; Staniforth, J.Z.; Ormerod, R.M.; Frost, C.D.; Parker, S.F.; Lennon, D. Quantification of surface species present on a nickel/alumina methane reforming catalyst. Phys. Chem. Chem. Phys. 2010, 12, 3102-3107. [CrossRef] [PubMed]

48. Di Paolo, T.; Bourdéron, C.; Sandorfy, C. Model Calculations on the Influence of Mechanical and Electrical Anharmonicity on Infrared Intensities: Relation to Hydrogen Bonding. Can. J. Chem. 1972, 50, 3161-3166. [CrossRef]

49. Lin-Vien, D.; Colthup, N.B.; Fateley, W.G.; Grasselli, J.G. The Handbook of Infrared and Raman Characteristic Frequencies of Organic Molecules; Elsevier: Amsterdam, The Netherlands, 1991.

50. Albers, P.W.; Weber, W.; Möbus, K.; Wieland, S.D.; Parker, S.F. Neutron scattering study of the terminating protons in the basic structural units of non-graphitising and graphitising carbons. Carbon 2016, 109, 239-245. [CrossRef]

51. Sadezky, A.; Muckenhuber, H.; Grothe, H.; Niessner, R.; Pöschl, U. Raman microspectroscopy of soot and related carbonaceous materials: Spectral analysis and structural information. Carbon 2005, 43, 1731-1742. [CrossRef]

52. Angoni, K. Remarks on the structure of carbon materials on the basis of Raman spectra. Carbon 1993, 31, 537-547. [CrossRef]

53. Jawhari, T.; Roid, A.; Casado, J. Raman spectroscopic characterization of some commercially available carbon black materials. Carbon 1995, 33, 1561-1565. [CrossRef]

54. Dresselhaus, M.S.; Jorio, A.; Saito, R. Characterizing graphene, graphite, and carbon nanotubes by Raman spectroscopy. Annu. Rev. Condens. Matter Phys. 2010, 1, 89-108. [CrossRef]

55. Albers, P.W.; Pietsch, J.; Krauter, J.; Parker, S.F. Investigations of activated carbon catalyst supports from different natural sources. Phys. Chem. Chem. Phys. 2003, 5, 1941-1949. [CrossRef]

56. Spencer, E.C.; Ross, N.L.; Parker, S.F.; Olsen, R.E.; Woodfield, B.F. Inelastic neutron scattering studies of hydrated CuO, ZnO and $\mathrm{CeO}_{2}$ nanoparticles. Chem. Phys. 2013, 427, 66-70. [CrossRef]

57. Zhu, X.; Lobban, L.L.; Mallinson, R.G.; Resasco, D.E. Bifunctional transalkylation and hydrodeoxygenation of anisole over a Pt/HBeta catalyst. J. Catal. 2011, 281, 21-29. [CrossRef]

58. Davidson, A.L.; Webb, P.B.; Parker, S.F.; Lennon, D. Hydrogen Partitioning as a Function of Time-on-Stream for an Unpromoted Iron-Based Fischer-Tropsch Synthesis Catalyst Applied to CO Hydrogenation. Ind. Eng. Chem. Res. 2020, 59, 52-60. [CrossRef]

59. Olcese, R.N.; Bettahar, M.; Petitjean, D.; Malaman, B.; Giovanella, F.; Dufour, A. Gas-phase hydrodeoxygenation of guaiacol over $\mathrm{Fe} / \mathrm{SiO}_{2}$ catalyst. Appl. Catal. B Environ. 2012, 115-116, 63-73. [CrossRef]

60. Li, C.; Nakagawa, Y.; Tamura, M.; Nakayama, A.; Tomishige, K. Hydrodeoxygenation of guaiacol to phenol over ceria-supported iron catalysts. ACS Catal. 2020, 10, 14624-14639. [CrossRef]

61. Tieuli, S.; Mäki-Arvela, P.; Peurla, M.; Eränen, K.; Wärnå, J.; Cruciani, G.; Menegazzo, F.; Murzin, D.Y.; Signoretto, M. Hydrodeoxygenation of isoeugenol over Ni-SBA-15: Kinetics and modelling. Appl. Catal. A Gen. 2019, 580, 1-10. [CrossRef]

62. Li, G.; Luo, Z.; Wang, W.; Cen, J. A study of the mechanisms of guaiacol pyrolysis based on free radicals detection technology. Catalysts 2020, 10, 295. [CrossRef]

63. Centeno, A.; Laurent, E.; Delmon, B. Influence of the support of CoMo Sulfide Catalysts and of the Addition of Potassium and Platinum on the Catalytic Performances for the hydrodeoxygenation of Carbonyl, Carboxyl, and Guaiacol-Type Molecules. J. Catal. 1995, 154, 288-298. [CrossRef]

64. Sulman, A.; Mäki-Arvela, P.; Bomont, L.; Alda-Onggar, M.; Fedorov, V.; Russo, V.; Eränen, K.; Peurla, M.; Akhmetzyanova, U.; Skuhrovcová, L.; et al. Kinetic and Thermodynamic Analysis of Guaiacol Hydrodeoxygenation. Catal. Lett. 2019, 149, $2453-2467$. [CrossRef]

65. Santos, J.L.; Mäki-Arvela, P.; Wärnå, J.; Monzón, A.; Centeno, M.A.; Murzin, D.Y. Hydrodeoxygenation of vanillin over noble metal catalyst supported on biochars: Part II: Catalytic behaviour. Appl. Catal. B Environ. 2020, 268. [CrossRef]

66. Tran, C.C.; Mohan, O.; Banerjee, A.; Mushrif, S.H.; Kaliaguine, S. A combined experimental and DFT investigation of selective hydrodeoxygenation of guaiacol over bimetallic carbides. Energy Fuels 2020, 34, 16265-16273. [CrossRef]

67. ISIS Neutron and Muon Source. Available online: https:/ /www.isis.stfc.ac.uk/Pages/home.aspx (accessed on 1 October 2021). 
68. Pinna, R.S.; Rudić, S.; Parker, S.F.; Armstrong, J.; Zanetti, M.; Škoro, G.; Waller, S.P.; Zacek, D.; Smith, C.A.; Capstick, M.J.; et al. The neutron guide upgrade of the TOSCA spectrometer. Nucl. Instrum. Methods Phys. Res. Sect. A Accel. Spectrom. Detect. Assoc. Equip. 2018, 896, 68-74. [CrossRef]

69. Parker, S.F.; Lennon, D.; Albers, P.W. Vibrational spectroscopy with neutrons: A review of new directions. Appl. Spectrosc. 2011, 65, 1325-1341. [CrossRef]

70. Ewings, R.A.; Stewart, J.R.; Perring, T.G.; Bewley, R.I.; Le, M.D.; Raspino, D.; Pooley, D.E.; Škoro, G.; Waller, S.P.; Zacek, D.; et al. Upgrade to the MAPS neutron time-of-flight chopper spectrometer. Rev. Sci. Instrum. 2019, 90, 1-18. [CrossRef] [PubMed] 